\title{
Pandemic Policing: Preparing a New Pathway for Māori?
}

\section{Elizabeth Stanley and Trevor Bradley, Victoria University of Wellington}

The government of Aotearoa/New Zealand has been widely praised for decisive actions during the Covid-19 pandemic. The official 'lockdown' (entailing closed borders, emergency powers and instructions for everyone to 'stay at home') was introduced before any community transmission of the virus. In early June 2020, there had been 22 deaths from Covid-19 in NZ and, at $8^{\text {th }}$ June 2020, there were no 'active' cases in the country. Life is returning to 'normal', notwithstanding stringent border controls.

Running alongside the praise, however, has been a raft of criticisms about how authorities have circumvented usual standards of protection to embed controls and expand state power in detrimental ways. In the criminal justice sphere, the pandemic has given rise to the hurried escalation of remote Court technologies that challenge due process, alongside burgeoning remand populations and long prison lockdowns with women at Auckland Women's Prison being kept to their cells for up to 29 hours at a time (Espiner, 2020; Lynch and Tinsley, 2020). More broadly, there has been a backlash about the scale of intrusions from new legislation. For example, the Covid-19 Public Health Response Act was rushed through under urgency, without any Māori consultation, in May 2020 as the country's Covid-19 cases were declining (Aikman, 2020a). The Act gives extraordinary powers for entry to premises, such that 'An enforcement officer may enter, without a warrant, any land, building, craft, vehicle, place, or thing' on 'reasonable grounds' (s.20(1)). It will sit on the statute books for two years but will require renewal every 90 days.

In this settler state, in which controls and punishments are differentially targeted on racialized grounds, Māori inevitably bear the brunt of increased controls, surveillance, incarceration or the removal of rights within the pandemic. In this respect, Covid-19 shifts are contextualised by a system in which Māori are over-policed, over-sentenced and overpunished (Whaipooti, 2020).

NZ Policing in 2020

These concerns can be illustrated with a focus on one criminal justice institution: the Police. NZ Police have long been reticent to acknowledge institutional or systemic racism, preferring instead to rely on the diluted ideas of 'unconscious bias'. In April 2020, for example, then Police Commissioner Mike Bush told the Epidemic Response Committee that while, historically, police discretion had 'not been applied evenly to different communities', the NZ Police 'now have data that says that...we apply that discretion evenly across communities' (cited in Aikman, 2020b). In support of the Commissioner's statement, the Minister of Police also claimed that NZ police were not institutionally racist (Daadler, 2020). 
Following public requests for the data on discretion decisions, the Commissioner later admitted that it did not exist (Aikman, 2020a) and, certainly, recent data indicates policing approaches that continue to target Māori. In May 2020, for example, NZ Police officers admitted that they had implemented a trial for facial rcognition surveillance (in conjunction with US company Clearview) without apparent clearance from the Minister of Police or even from senior police officers. Officers further conceded that Clearview Al software was used to search for dozens of 'wanted' New Zealanders including people that 'looked Maori or Pasifika' (Smith, 2020).

The following month, in June 2020, data from a six-month trial for 'Armed Response Teams' (ARTs) showed that of the 921 people apprehended for offences, 49\% ( $n=453)$ were Māori (NZ Police, 2020) - Māori are $16.5 \%$ of the general NZ population. The ARTs were first established following the white supremacist killing of 51 Muslims at prayer in Christchurch, Canterbury. Operating across three sites (including Canterbury, Waikato and Counties Manukau), it appears that most ART-attended incidents (74\%) have occurred outside Canterbury (NZ Police, 2020). Further, armed police attended 8,629 incidents, of which 2,195 (25\%) were 'turnovers' or traffic stops (NZ Police, 2020). Implemented without Māori consultation, the Teams have become the subject of a Waitangi Tribunal claim (WAI 2944).

Recently released police data also makes clear that, during the 'lockdown', Māori continued to disproportionately experience police warnings and court proceedings. Māori made up $40.2 \%$ of those in offence categories related to Covid-19 breaches - such as 'offences against justice procedures, government security, and government operations' (Daalder, 2020). During March-April 2020, Māori were four times more likely to experience legal proceedings than Pākehā [NZ Europeans] (Daalder, 2020). And, while 34.6\% Māori received a formal warning, Māori were $46.6 \%$ of those appearing in court (Daalder, 2020), illustrating how Indigenous people are persistently funnelled into the more serious end of proceedings. In short, the crises gifted additional opportunities for continued applications of unfavourable police discretion against Māori, further amplifying their disproportionate representation in police 'proceedings' and criminal justice (Whaipooti, 2020).

The above realities reflect a situation in which official responses to change and crises (of pandemic, of mass killing, of new technological developments) reiterate and reinforce the structural and institutional settings of state agencies. The contemporary experiences of policing in NZ have re-emphasised the colonial discrimination inherent in criminal justice processes. They have also re-demonstrated that the Treaty of Waitangi ${ }^{1}$ is ignored or

${ }^{1}$ Te Tiriti o Waitangi/The Treaty of Waitangi is an 1840 'constitutional' document, signed by
British Crown representatives and Māori chiefs. The English and Māori versions of the
Treaty do not say the same thing. For example, in the English version, Māori cede
sovereignty to the Crown. In the Māori version, Māori cede Kāwanatanga (Governance) and 
downplayed in most aspects of state decision-making and practice. The exposure of these settings has, once more, brought state actions under a critical spotlight, with a common warning that the NZ government and authorities like NZ Police face reductions in public trust, confidence and legitimacy, from Māori but also from Pasifika and other minority populations.

\section{Pandemic Policing by Māori}

Despite these concerns, there are nuanced experiences to be registered through the Covid19 pandemic, one of which relates to how some Māori spontaneously formed different and more engaged relationships with NZ Police to provide protections. These relationships emerged out of necessity as Māori communities (holding memories of the devastating losses suffered during the 1918 influenza pandemic, in which Māori died at eight times the rate of Pākehā) understood that they had to resist government Covid-19 responses that did not specifically protect Māori health and well-being (Ngata, 2020). This spurred the establishment of Iwi (or tribal) roadside checkpoints to manage access to areas with significant Māori populations, particularly those with 'existing or historical health risk' (Harris and Williams, 2020; Ngata, 2020). Up to 50 checkpoints were initially set up at various locations, including in Northland, East Coast, Bay of Plenty, Taranaki and Christchurch. They sought to limit travel to Mãori communities and to challenge 'the potentially devastating impact of Covid-19' on local populations (Peters, 2020). The checks undertaken by Māori, generally with NZ Police presence - could not force changes to travel but strongly encouraged travellers to limit their movements and return home.

Right wing politicians and commentators contested these checkpoints, claiming they were unlawful or illegitimate (Harris and Williams, 2020; Newman, 2020). In response, NZ Police Commissioner Andrew Coster (2020) took a different view. He noted that: 'With minor exceptions, police were satisfied that the action being taken in these communities was strongly aligned to the controls that the Government had put in place, and community interactions were positive and enhancing community safety'. Indeed, legal settings (including legislation for policing, local government, public health or civil defence) provide opportunities for 'individual citizens, or agencies or bodies other than the Police' to perform policing functions, and for Māori to participate in delivering health services or local government activities (Harris and Williams, 2020).

were guaranteed Tino Rangatiratanga (sovereignty) o ratou wenua o ratou kainga me o ratou taonga katoa (over lands, settlements, and all other treasures). The Treaty remains contested. However, from the 1980s, principles have developed to redefine the relationship between the Treaty partners. These include kāwanatanga (Governance), Rangatiratanga (Self-Management), Partnership, Equality, Redress and Reasonable Cooperation. Government agencies, among others, are obliged to enact the Treaty through legislation, policy and practice. 
For many Māori, the checkpoints also reflected a more substantive shift in government relations. As one organiser of checkpoints on the East Coast, Tina Ngata, reflected: 'For me, it's the closest to the Treaty relationship that I've seen from police...they're taking guidance from the local communities and accepting that we know our communities best and looking at how we can work together' (Johnsen, 2020).

\section{Policing through Partnerships}

The Covid-19 crisis generated an opportunity for Māori communities to re-establish some degree of community control and tino rangatiratanga (self-determination) over local policing and safety strategies. These spontaneous actions to a global pandemic reflect an opportunity to not merely 'fine tune' or improve existing partnerships between Māori and NZ Police but to reimagine and recast those relationships.

We contend that the Māori achievement of greater policing autonomy does not require the introduction of new legislation or the creation of new, specialist institutions but it will require NZ Police and government to adopt new and more flexible perspectives on what it means to 'police', how it can be delivered and by whom. Currently, various legislative frameworks offer support for Māori to take on greater policing responsibilities. Among these, the Treaty of Waitangi entitles Māori to a significant role in deciding on the form of their institutions for self-government through the concepts of kāwanatanga (the right to govern and exercise good government), tino rangatiratanga (the right to self-government and autonomy) and partnership (Waitangi Tribunal, 2014: 33). However, other laws - such as the Policing Act 2008 and the Local Government Act 2002 provide clear pathways for: policing co-operation with local communities; 'citizen policing'; Māori self-determination; and democratic decision-making and action by communities (Harris and Williams, 2020).

It is also clear that the step to greater policing autonomy could crystallize from established community-oriented actions, such as from NZ Police's use of Watene Māori/Maori Wardens and Te Pae Oranga/Iwi Community Panels. Both of these initiatives - the first focused on building community controls and the second on community alternatives to prosecution are embedded within NZ Police operations. At present, they are relatively limited in scope, under-supported and non-independent. However, they offer the promise of a genuinely different way of policing Māori communities. Extending the lines of Māori policing - that could exist in truly autonomous and properly resourced ways - would centralise Māori justice practices and philosophies, and help New Zealand to reduce the over-policing, criminalisation and over-punishment of Māori.

\section{Conclusion}


The Covid-19 pandemic has re-exposed the need for state organisations to cede power and allow Māori 'to develop or have the authority to implement their own initiatives' (Jackson 1988: 164). The checkpoints, emerging from spontaneous Māori action, undoubtedly protected Māori communities from Covid-19. Widely regarded as successful in halting virus spread, these responses also served to reiterate the fundamental limits of state protection for Māori and the requirement for greater policing autonomy in Māori communities (as required under the Treaty of Waitangi, and as enabled through wider legislation). In this respect, the Covid-19 pandemic highlighted that NZ government must further empower Māori to develop culturally appropriate ways of policing, that are independent of NZ Police. As demonstrated here, there are already processes in place from which to build. These decolonizing shifts would require more than a commitment to adequate resources 'but a commitment to understanding' and an acceptance that Māori solutions to offending 'often move beyond the accepted solution shaped by Pakeha perceptions' (Jackson, 1988: 166).

\section{References}

Aikman P (2020a) 'Partnership is Critical During a Crisis', E-Tangata, 24 May 2020. Accessed at: https://e-tangata.co.nz/comment-and-analysis/partnership-is-critical-during-a-crisis/

Aikman P (2020b) 'We Don't Have to Go Down this Path', E-Tangata, 26 April 2020.

Accessed at: https://e-tangata.co.nz/comment-and-analysis/we-dont-have-to-go-down-thispath/

Coster A (2020) 'Coronavirus: Iwi Checkpoints were about Safety and Discretion', Stuff News, 4 May 2020. Accessed at:

https://www.stuff.co.nz/national/health/coronavirus/121400826/coronavirus-iwicheckpoints-were-about-safety-and-discretion

Daalder M (2020) 'Māori over-represented in lockdown police proceedings', Newsroom, 3 June 2020. Accessed at: https://www.newsroom.co.nz/2020/06/03/1216951/maorioverrepresented-in-lockdown-police-proceedings

Espiner G (2020) Covid-19: Prisoners Confined to Cells for Up to 29 Hours, Diary Shows', RNZ, 1 May 2020. Accessed at: https://www.rnz.co.nz/news/national/415563/covid-19prisoners-confined-to-cells-for-up-to-29-hours-diary-shows

Harris M and Williams D (2020) 'Community Checkpoints are an Important and Lawful Part of NZ's Covid Response', The Spinoff, 10 May 2020. Accessed at:

https://thespinoff.co.nz/society/10-05-2020/community-checkpoints-an-important-andlawful-part-of-nzs-covid-response/ 
Jackson M (1988) The Maori and the Criminal Justice System A new perspective: He Whaipaanga Hou, Part 2, Wellington, Department of Justice.

Johnsen M (2020) 'Covid-19: Remote Communities in Far North want Checkpoints to Remain in Level 2', RNZ, 13 May 2020. Accessed at: https://www.rnz.co.nz/news/te-manukorihi/416492/covid-19-remote-communities-in-far-north-want-checkpoints-to-remain-in$\underline{\text { level-2 }}$

Lynch N and Tinsley Y (2020) 'Court Adjourned: How the Pandemic is Delaying Justice in Criminal Cases', The Spinoff, 12 May 2020. Accessed at: https://thespinoff.co.nz/society/1205-2020/court-adjourned-how-the-pandemic-is-delaying-justice-in-criminal-cases/

Ngata T (2020) 'Covid-19 and the Māori Duty to Protect', Overland, 7 May 2020. Accessed at: https://overland.org.au/2020/05/covid-19-and-the-maori-duty-toprotect/?fbclid=IwAR2tDMCjVsn9PY5XYmSnMJ wvCnQCqY0iKKW1UJQf7sDJTwD6IgPkhdpIM

NZ Police (2020) Armed Response Teams trial Data on Incidents and Offences, June 2020. Available at: https://www.police.govt.nz/about-us/publication/armed-response-teams-trialdata-incidents-and-offences

Peters M (2020) Checkpoints on Coast, Gisborne Herald, 24 March 2020. Accessed at: http://www.gisborneherald.co.nz/local-news/20200324/protecting-the-most-vulnerable/

Waitangi Tribunal (2014) Whaia te Mana Motuhake - In Pursuit of Mana Motuhake: Report on the Māori Community Development Act Claim (WAI 2417), Wellington: Waitangi Tribunal.

Whaipooti J (2020) 'Minneapolis has vowed to defund its police. New Zealand needs to have that conversation', The Guardian, 10 June. Accessed at:

https://www.theguardian.com/world/2020/jun/10/minneapolis-has-vowed-to-defund-itspolice-new-zealand-needs-to-have-that-conversation. 